\title{
HGF and the regulation of tight junctions in human prostate cancer cells
}

\author{
TRACEY A. MARTIN ${ }^{1}$, MALCOLM D. MASON ${ }^{2}$ and WEN G. JIANG ${ }^{1}$ \\ ${ }^{1}$ Cardiff University-Peking University Cancer Research Institute; ${ }^{2}$ Institute of Cancer and Genetics, \\ Cardiff University School of Medicine, Cardiff, CF14 4XN, UK
}

Received February 14, 2014; Accepted April 30, 2014

DOI: $10.3892 /$ or.2014.3219

\begin{abstract}
Hepatocyte growth factor (HGF) may impact the metastasis of prostate cancer via its action on prostate stem cells or their progeny. Tight junctions (TJs) are crucial to the process of metastasis and have been previously shown to be regulated by HGF. The present study aimed to evaluate the effect of HGF on the function of TJs in human prostate epithelial, prostate stem cell-like and prostate cancer cell lines. Four human prostate cancer cell lines (PC-3, DU-145, PZHPV-7, CaHPV-10), normal adult prostate parental epithelial cells (RWPE-1) and a stem cell-like derivative of RWPE-1 (WPE-STEM) were used to assess HGF-induced changes in TJs. A significant difference was noted in the behaviour between the WPE-STEM, RWPE-1 and the cancer cell lines which was HGF concentration-dependent. However, in the WPE-STEM cells, the effect was biphasic, with the cells seemingly resistant to HGF-modulated TJ disruption. Closer examination revealed that $\mathrm{HGF}$ affected the redistribution of ZO-1, ZO-2 and ZO-3 away from the TJs of confluent cells with concurrent loss of claudin-1 and claudin-5, and western blot analysis revealed a loss in TJ protein expression of $\mathrm{ZO}-1$ and $\mathrm{ZO}-2$. We demonstrated for the first time that HGF regulates TJ function in human prostate cells. Moreover, this regulation was dependent on the tumourigenicity of the cells, with the most aggressive cells most susceptible and the stem cell-like cells least susceptible. These data offer an intriguing glimpse of how TJs affect the behaviour of prostate cancer cells and how HGF modulates the expression and function of the molecules maintaining $\mathrm{TJ}$ structure and function.
\end{abstract}

\section{Introduction}

The major impact of hepatocyte growth factor (HGF) on the development and metastasis of prostate cancer may be via its

Correspondence to: Dr Tracey A. Martin, Cardiff UniversityPeking University Cancer Research Institute, Cardiff University School of Medicine, Heath Park, Cardiff CF14 4XN, UK

E-mail:martinta1@cf.ac.uk

Key words: tight junctions, prostate cancer, stem cell-like, HGF action on prostate stem cells or their progeny. Understanding the sequence of events in the above process would have important implications in understanding the biology of prostate cancer and in the development of new therapies. Stem cells constitute a small population of relatively undifferentiated cells that express no differentiation markers of tissue and exhibit diverse expression of tight junction (TJ) proteins.

TJs are crucial to the process of metastasis and have been previously shown to be regulated by HGF. TJs are the apical cellular structure of both epithelial and endothelial cells and play a key role in the control of paracellular passage and cell adhesion. Previous studies have demonstrated a correlation between a reduction in TJs and tumour differentiation, and experimental evidence has emerged that places TJs as the frontline structures that tumour cells must overcome in order to successfully metastasize (1-5). Although a considerable body of research exists on TJs and their role in a number of diseases, it is only in the last few years that their possible role in tumourigenesis and tumour progression has been studied. Yet, to date, most of the research has focused on cell lines and to a limited degree on colorectal and pancreatic cancers, with a few studies carried out on breast cancer concentrating on claudin-1 (SEMP-1), claudin-7, ZO-1 and ZO-2 expression (5-10).

Changes in the expression of TJ proteins may be due to regulatory mechanisms or promoter methylation. Regulatory mechanisms may be via the suggested pathway of epithelial-tomesenchymal transition (EMT) as the process of acquisition of an invasive phenotype by tumours of epithelial origin can be regarded as a pathological version of EMT $(11,12)$. TJs determine epithelial cell polarity and disappear during EMT. Snail and Slug are factors thought to be responsible for this loss (13). Regulation also occurs via the Rho GTPase family, which is able to regulate TJ assembly (14). Thus, TJs can be regulated in response to physiological and tissue-specific requirements (15). TJs are able to rapidly change their permeability and functional properties in response to stimuli, permitting dynamic fluxes of ions and solutes in addition to the passage of whole cells. HGF, a cytokine secreted by stromal cells, was found to modulate the expression and function of TJ molecules in human breast cancer cell lines (10). HGF decreased the transepithelial resistance and increased the paracellular permeability of human breast cancer cell lines, MDA-MB-231 and MCF-7. qPCR revealed that HGF 
modulated the levels of several TJ molecule (occludin, claudin-1, claudin-5, JAM-1 and JAM-2) mRNA transcripts in MDA-MB-231 and MCF-7 cells. Western blotting and immunohistochemistry also showed modulation of expression of the TJ molecule, occludin. It was suggested that HGF disrupts $\mathrm{TJ}$ function in human breast cancer cells by affecting changes in the expression of TJ molecules at both the mRNA and protein levels. It has also been shown that HGF treatment results in disassociation of MCF-7 and T47D cells in culture, and a loss of claudin-7 expression within $24 \mathrm{~h}$ (6).

Few studies have reported on the role of TJs in prostate cancer. Those studies that were carried out focused on clinical samples and investigated the expression of claudins (16-19) even though there was an interest in the role of TJs in the prostate early on (20-23) which has not been further researched.

Our present study, therefore, aimed to determine whether HGF plays a similar role in the regulation of TJs in human prostate cells. Cells were subjected to HGF treatment and the distribution and expression of ZO-1, ZO-2, ZO-3, occludin, claudin- 1 and claudin-5 were determined. Any changes in junctional integrity were also assessed. The data obtained showed that HGF was able to regulate the function of TJs in human prostate cells by modulating the expression of a number of TJ molecules at the molecular and protein levels. It is anticipated that further studies will reveal an important role of TJs in prostate cancer cell behaviour.

\section{Materials and methods}

Reagents and antibodies. Anti-occludin (N-19 epitope, sc-8145 and H-279 epitope, sc-5562), anti-ZO-1, anti-ZO-2, anti-ZO-3, anti-claudin-1, anti-claudin-5, anti-AF6 and anti$\beta$-actin (sc-8432) antibodies were purchased from Santa Cruz Biotechnology (Santa Cruz, CA, USA) and Pharmingen International (San Diego, CA, USA). The anti-occludin (c-terminal epitope, 71-1500) antibody was purchased from Zymed (Invitrogen Ltd., Paisley, UK). Peroxidase-conjugated anti-mouse and anti-rabbit IgG for western blotting were from Sigma-Aldrich (Poole, UK). FITC- or TRITC-conjugated anti-mouse, anti-goat and anti-rabbit IgG were from SigmaAldrich. FITC-conjugated dextran $(40 \mathrm{kDa})$ was obtained from Molecular Probes (Eugene, OR, USA). Carbonate filter inserts with a pore size of $0.4 \mu \mathrm{m}$ (for 24-well plates) were from Greiner Bio-One Ltd. (Stonehouse, Glos, UK). Gold electrode arrays (8W10E) were purchased from Applied Biophysics Inc. (Troy, NY, USA).

Cell lines. Human prostate cancer cell lines PC-3, DU-145, CAHPV-10, PZHPV-7 and LNCap [European Collection of Animal Cell Cultures (ECACC), Wiltshire, UK] were routinely maintained in Dulbecco's modified Eagle's medium (DMEM; Sigma-Aldrich) supplemented with $10 \%$ foetal calf serum (FCS), penicillin and streptomycin (Sigma-Aldrich). RWPE-1, a normal adult prostate parental epithelial cell and WPESTEM, a stem cell-like derivative of RWPE-1 (ATCC, LGC Standards, Teddington, UK) were routinely cultured using the keratinocyte serum-free medium (K-SFM) kit [Invitrogen (Gibco); cat. no. 17005-042] with bovine pituitary extract (BPE) and human recombinant epidermal growth factor (EGF).
Transepithelial resistance (TER). TER was measured using an EVOM Volt-Ohm meter (EVOL, World Precision Instruments, Aston, Herts, UK), equipped with a pair of STX-2 chopstick electrodes (WPI, Sarasota, FL, USA), as we previously reported $(10,24)$. Briefly, cells were seeded into the $0.4-\mu \mathrm{m}$ pore size insert (Greiner Bio-One Ltd., Stonehouse, Glos, UK) and allowed to reach full confluency, after which fresh medium was replaced for further experiments. Inserts without cells, inserts with cells in medium and inserts with cells with HGF (at varying concentrations) were tested for a period of $2 \mathrm{~h}$. Electrodes were placed at the upper and lower chambers, and resistance was measured with the Volt-Ohm meter.

Immunofluorescence staining of human prostate cancer cells. For immunofluorescence staining, cells $(30,000$ cells/well) were grown in 16-well chamber slides (LAB-TEK International, Sussex, UK) and incubated at $37^{\circ} \mathrm{C}$ in a $5 \%$ incubator for a set period of time (0-24 h). After incubation, the culture medium was aspirated, the wells were rinsed with balanced salt solution (BSS) buffer and the cells were fixed in methanol for $20 \mathrm{~min}$ at $-20^{\circ} \mathrm{C}$. After fixation, the cells were washed twice using BSS buffer and permeabilised by the addition of $200 \mu \mathrm{l}$ of $0.1 \%$ Triton X-100 (Sigma-Aldrich) detergent in phosphatebuffered solution (PBS) for $5 \mathrm{~min}$ at room temperature. Cells were rinsed twice with PBS buffer, and $200 \mu 1$ of blocking buffer (10\% horse serum in PBS) was added to each well and the chamber slide was incubated for $40 \mathrm{~min}$ at room temperature on a bench rocker. The wells were washed once with wash buffer (3\% horse serum in TBS buffer containing $0.1 \%$ Tween-20), and $100 \mu \mathrm{l}$ of the primary antibodies prepared in wash buffer was added to the appropriate wells. The chamber slide was incubated on the rocker for a further $60 \mathrm{~min}$ at room temperature. Wells were washed twice with TBS buffer (with $0.1 \%$ Tween-20), and the cells were incubated in $100 \mu \mathrm{l}$ of the secondary antibodies [fluorescein isothiocyanate (FITC) or tetramethylrhodamine isothiocyanate (TRITC) conjugates; Sigma-Aldrich] (diluted in the same manner as the primary antibodies) for $50 \mathrm{~min}$. The chamber slide was wrapped in foil to prevent light from reaching the conjugate. Finally, the wells were rinsed twice with wash buffer, and once in BSS buffer mounted with FluorSave ${ }^{\mathrm{TM}}$ (Calbiochem-Novabiochem Ltd., Nottingham, UK) reagent and visualised using an Olympus BX51 microscope with a Hamamatsu (Welwyn Garden City, Herts, UK) Orca ER digital camera at a magnification of x100 using an oil immersion lens.

SDS-PAGE and western blotting. Total cell lysates and tissues were prepared as follows. Cells were pelleted and lysed in HCMF buffer plus $0.5 \%$ SDS, $0.5 \%$ Triton X-100, $2 \mathrm{mM} \mathrm{CaCl}_{2}$, $100 \mu \mathrm{g} / \mathrm{ml}$ phenylmethylsulfonyl fluoride, $1 \mathrm{mg} / \mathrm{ml}$ leupeptin, $1 \mathrm{mg} / \mathrm{ml}$ aprotinin and $10 \mathrm{mM}$ sodium orthovanadate for $40 \mathrm{~min}$. Sample buffer was added, and the proteins were boiled at $100^{\circ} \mathrm{C}$ for $5 \mathrm{~min}$ before clarification at $13,000 \mathrm{x} \mathrm{g}$ for $10 \mathrm{~min}$. Equal amounts of protein from each cell sample were added onto an $8 \%$ polyacrylamide gel. Following electrophoresis, proteins were blotted onto nitrocellulose sheets and blocked in 10\% horse serum for $60 \mathrm{~min}$ before probing with the specific primary antibodies, followed with the peroxidaseconjugated secondary antibody $(1: 2,000)$. Protein bands were visualised with the Supersignal West Dura Extended Duration 
substrate chemiluminescent system (Perbio Science UK Ltd., Cramlington, UK) and detected using a CCD UVIprochemi system (UVItec Ltd., Cambridge, UK).

Electric cell-substrate impedance sensing measurements. The electric cell-substrate impedance sensing (ECIS, Applied Biophysics, Troy, NY, USA) system was used to measure transepithelial impedance in order to ascertain differences in barrier function in the presence or absence of HGF as a potential regulator of TJ function. For ECIS measurements, $10^{4}$ cells were seeded into each well of an electrode array $(96 \mathrm{~W} 10 \mathrm{E}$ or $8 \mathrm{~W} 10 \mathrm{E})$. Medium $(0.4 \mathrm{ml} /$ well $)$ was added, and after $24 \mathrm{~h}$ in culture, confluence and viability of the cell monolayer were confirmed by light microscopy and electrically. Impedance data were obtained from cell-covered electrode arrays using a $1-\mathrm{V}$ AC signal at $4,000 \mathrm{~Hz}$.

Statistical analysis. Statistical analysis was performed by Minitab version 13.32 (Minitab Inc., State College, PA, USA) using a two-sample Student's t-test.

\section{Results}

Redistribution of TJ proteins during HGF co-culture. Confluent cultures of all 4 prostate cell lines exhibited normal $\mathrm{TJ}$ location as visualised using immunofluorescence. $\mathrm{ZO}-1$, ZO-2 and ZO-3 were observed at the cell-cell junctions of the cells, as were occludin and claudin-1. For the most part, claudin-5 was found less obviously at the cell membrane, but quite extensively in the peri-nuclear region (Fig 1).

In the PC-3 cells, after a 0.5 -h co-culture with HGF ( $25 \mathrm{ng} /$ $\mathrm{ml}$ ) a reduction in the cell junction location of $\mathrm{ZO}-1$ was noted, which by $1 \mathrm{~h}$ had resulted in a loss of ZO-1 at the cell periphery and an increased signal at the peri-nuclear region (Fig. 1). This was more pronounced at 2 and $4 \mathrm{~h}$ of co-culture. After a $24-\mathrm{h}$ treatment, there was some re-establishment of ZO-1 at the cell-cell junctions. There was a similar re-distribution of ZO-2, albeit a slower reduction at the cell-cell junction (at $1 \mathrm{~h}$ not $0.5 \mathrm{~h}$ as with ZO-1), although after a 24-h co-culture, re-location to the cell periphery was not complete. Concomitant with this was the change in location of ZO-3 (Fig. 1). In contrast, the location of occludin did not show such changes after treatment with HGF. Although the staining pattern became 'spotty' by $1 \mathrm{~h}$ of co-culture, there was altogether, no loss of this protein from the cell periphery. However, claudin-1 expression was lost by $0.5 \mathrm{~h}$ of co-culture and did not recover after $24 \mathrm{~h}$. Claudin-5 distribution was lost by a 1-h treatment and also did not recovered by $24 \mathrm{~h}$. It was observed that claudin- 5 expression was overall more intense than claudin-1 expression.

In the DU-145 cells, expression of ZO-1 was not noticeably reduced until $4 \mathrm{~h}$ of co-culture with HGF and recovered fully by $24 \mathrm{~h}$ (Fig. 2). A similar pattern was also observed with ZO-2. ZO-3 expression, however, was reduced by $1 \mathrm{~h}$ of co-culture with HGF and recovery to the cell membrane was visible after $4 \mathrm{~h}$ of co-culture. In comparison to PC-3 cells, occludin was strongly visible at the cell periphery in DU-145 cells and co-culture with HGF did not greatly reduce the expression of this protein. Some spotting was noticeable by $4 \mathrm{~h}$ of co-culture with HGF, but the TJ staining pattern was clearly visible. Claudin-1 was lost from the cell junctions after only
30 min of co-culture with HGF and became spotty after $1 \mathrm{~h}$ in DU-145 cells. Recovery to the TJs was almost complete by $2 \mathrm{~h}$ of co-culture. Claudin-5 was weakly stained in the control DU-145 cells, together with strong peri-nuclear staining. This was more concentrated around the nucleus after just $30 \mathrm{~min}$ of co-culture with HGF, but re-location to the cell periphery was apparent after $2 \mathrm{~h}$.

CAHPV-10 cells exhibited clear junctional staining for ZO-1 that was lost completely by $1 \mathrm{~h}$ of co-culture with HGF (Fig. 3). There was relocation towards the nucleus which had only just dissipated by $24 \mathrm{~h}$ of co-culture with HGF. ZO-2 expression was very strong in the CAHPV-10 cells and became dotty and almost completely lost from the cell periphery after $1 \mathrm{~h}$ of HGF treatment. Location of ZO-2 at the $\mathrm{TJ}$ area was almost reconstituted after $4 \mathrm{~h}$. In contrast, ZO-3 was weakly located at the cell periphery in the CAHPV-10 cells and appeared to increase at the cell periphery after HGF treatment. Occludin was shown to be located at both the cell membrane and nuclear membrane in the CAHPV-10 cells, both of which were reduced by $2 \mathrm{~h}$ of co-culture with HGF. By $24 \mathrm{~h}$ of co-culture, cell membrane integrity appeared to be intact, but there was no return of occludin to the nuclear region. Claudin-1 was lost from the cell membrane after 30 min of treatment with HGF, and re-location was apparent after only $1 \mathrm{~h}$. The location of claudin-5 was again visible in the peri-nuclear region of CAHPV-10 cells and there appeared to be an increase in intensity after treatment with HGF.

ZO-1 was lost from the cell membrane in the PZHPV-7 cells after a 2-h treatment with HGF (Fig. 4). There appeared to be a stronger staining towards the leading edge of the cell. Recovery to the cell membrane was slow and not complete after a 24-h culture. ZO-2 staining became spotty at the cell membrane after $30 \mathrm{~min}$ of co-culture with HGF but recovered by $2 \mathrm{~h}$. The pattern of staining of ZO-3 in the PZHPV-7 cells was very weak, although visible at the cell membrane before HGF treatment and was completely lost by a $30-\mathrm{min}$ co-culture. Levels had recovered by $24 \mathrm{~h}$. Occludin was not completely lost from the cell membrane in the PZHPV-7 cells but was dotty after a 30-min co-culture with HGF. Claudin-1 was reduced at the cell periphery and showed increased cytoplasmic staining in the PZHPV-7 cells by $2 \mathrm{~h}$ of co-culture with HGF before recovery by $4 \mathrm{~h}$. Claudin- 5 was strongly stained in the peri-nuclear region of PZHPV-7 cells, weakly stained at the cell membrane and remained so until $24 \mathrm{~h}$ of treatment with HGF, when there was some relocation to the cell periphery.

Changes in transepithelial resistance (TER) of cells during HGF co-culture. Co-culture of confluent PC-3 cells with HGF at increasing concentrations resulted in a marked reduction in TER over $24 \mathrm{~h}$ as compared to the control cells (Fig. 5A). This occurred in a concentration-dependent manner, with the highest concentration of HGF $(100 \mathrm{ng} / \mathrm{ml})$ causing the greatest reduction in resistance. Maximum reduction was achieved after $4 \mathrm{~h}$ of treatment with HGF (control vs. HGF $25 \mathrm{ng} / \mathrm{ml}, \mathrm{P}<0.0001 ; 50 \mathrm{ng} / \mathrm{ml}, \mathrm{P}=0.0004 ; 100 \mathrm{ng} / \mathrm{ml}$ $\mathrm{P}<0.0001)$. A similar effect was observed in the DU-145 cells treated with HGF (Fig. 5B); however, the greatest reduction in TER was achieved by HGF at $50 \mathrm{ng} / \mathrm{ml}$. Maximum effect of HGF at all concentrations occurred following $4 \mathrm{~h}$ of treatment 


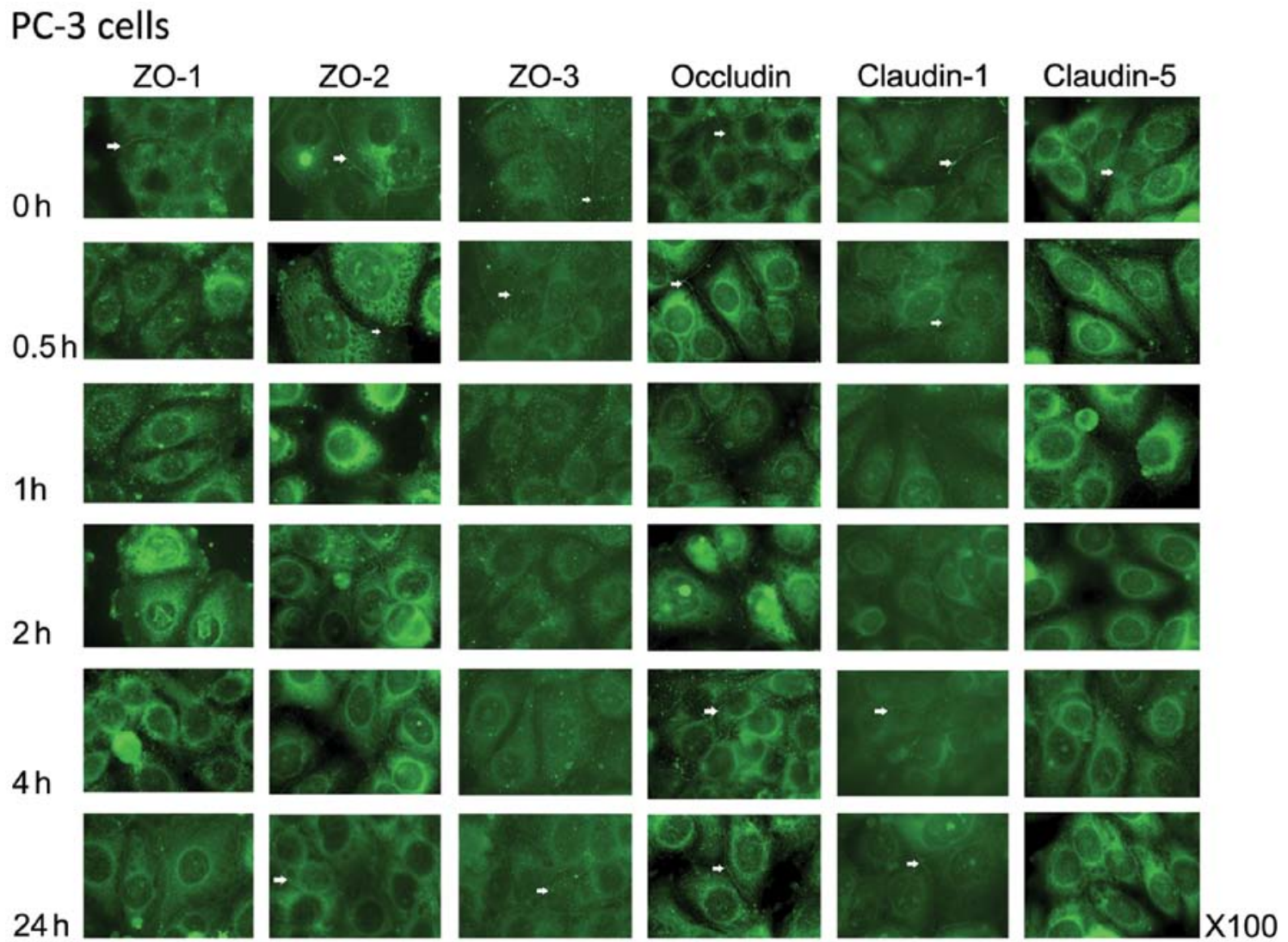

Figure 1. Immunohistochemical staining demonstrating the change in distribution of TJ proteins from the TJs after co-culture with $\mathrm{HGF}$ ( $25 \mathrm{ng} / \mathrm{ml})$ over $24 \mathrm{~h}$ in PC-3 human prostate cancer cells. The arrows indicate the correct location of expression of the protein.

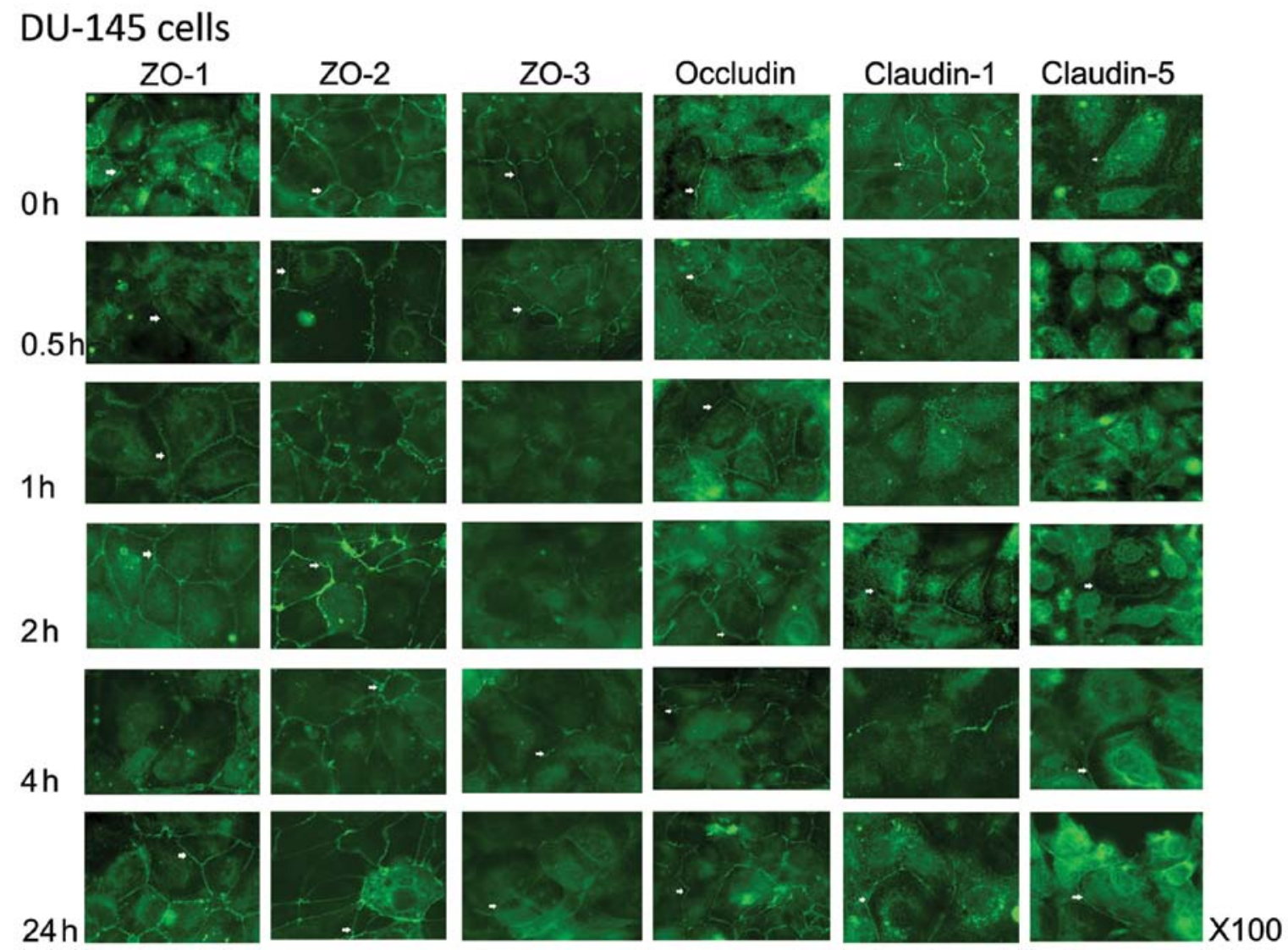

Figure 2. Immunohistochemical staining demonstrating the change in distribution of TJ proteins from the TJs after co-culture with $\mathrm{HGF}$ ( $25 \mathrm{ng} / \mathrm{ml}$ ) over $24 \mathrm{~h}$ in DU-145 human prostate cancer cells. The arrows indicate the correct location of expression of the protein. 
CAHPV-10 cells

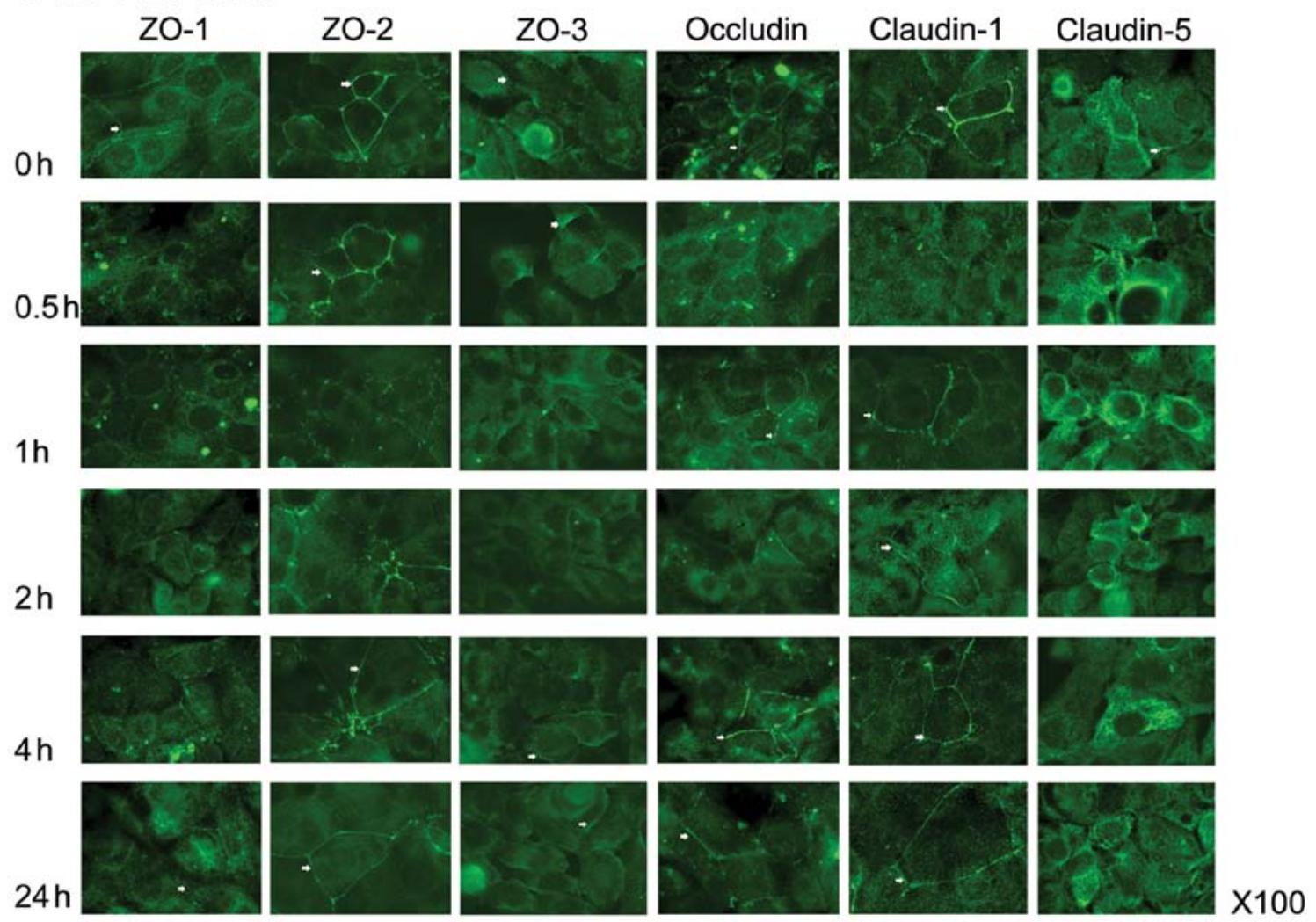

Figure 3. Immunohistochemical staining demonstrating the change in distribution of TJ proteins from the TJs after co-culture with HGF ( $25 \mathrm{ng} / \mathrm{ml}$ ) over $24 \mathrm{~h}$ in CAHPV-10 human prostate cancer cells. The arrows indicate the correct location of expression of the protein.

\section{PZHPV-7 cells}

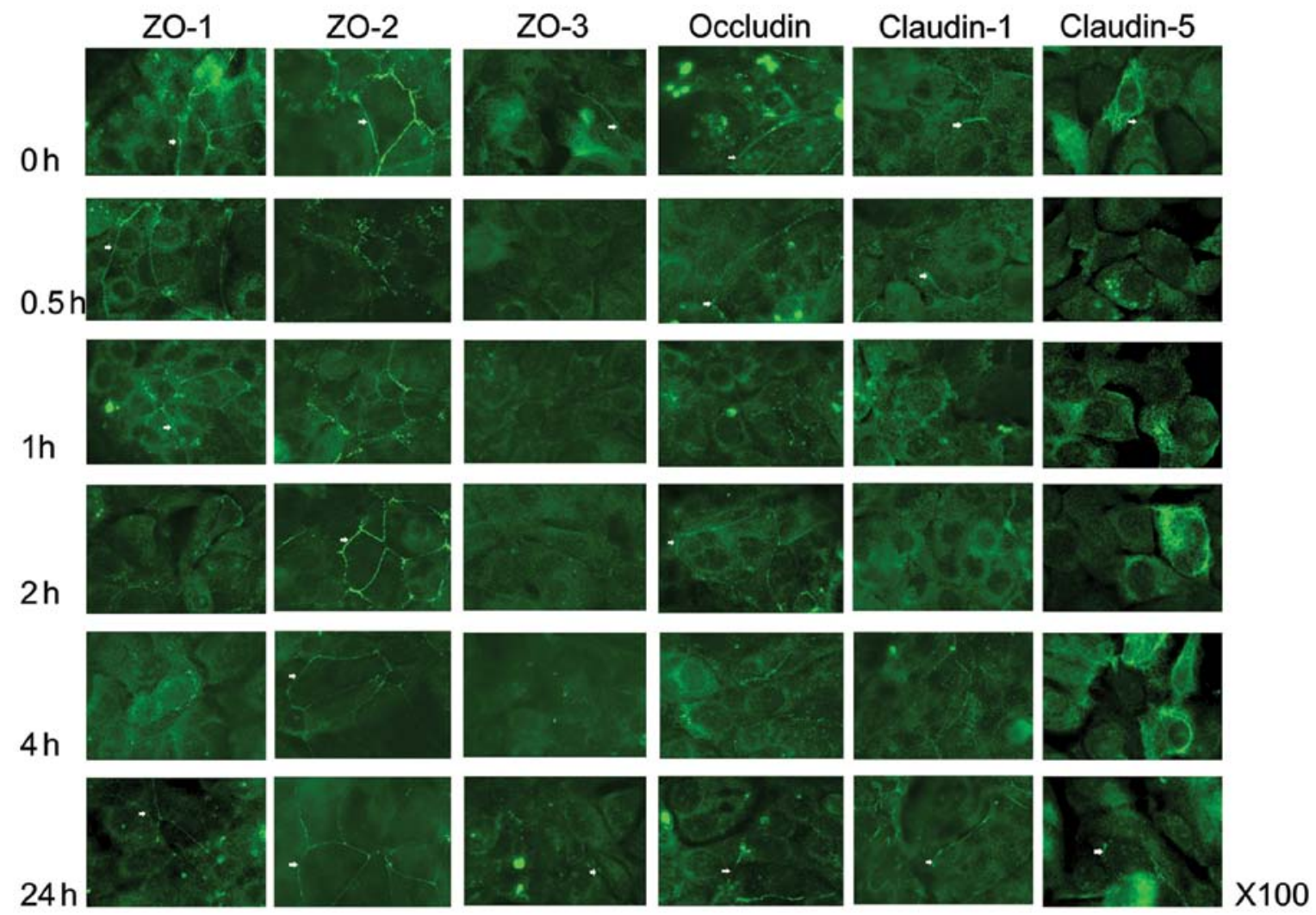

Figure 4. Immunohistochemical staining demonstrating the change in distribution of TJ proteins from the TJs after co-culture with $\mathrm{HGF}$ ( $25 \mathrm{ng} / \mathrm{ml}$ ) over $24 \mathrm{~h}$ in PZHPV-7 human prostate cancer cells. The arrows indicate the correct location of expression of the protein. 

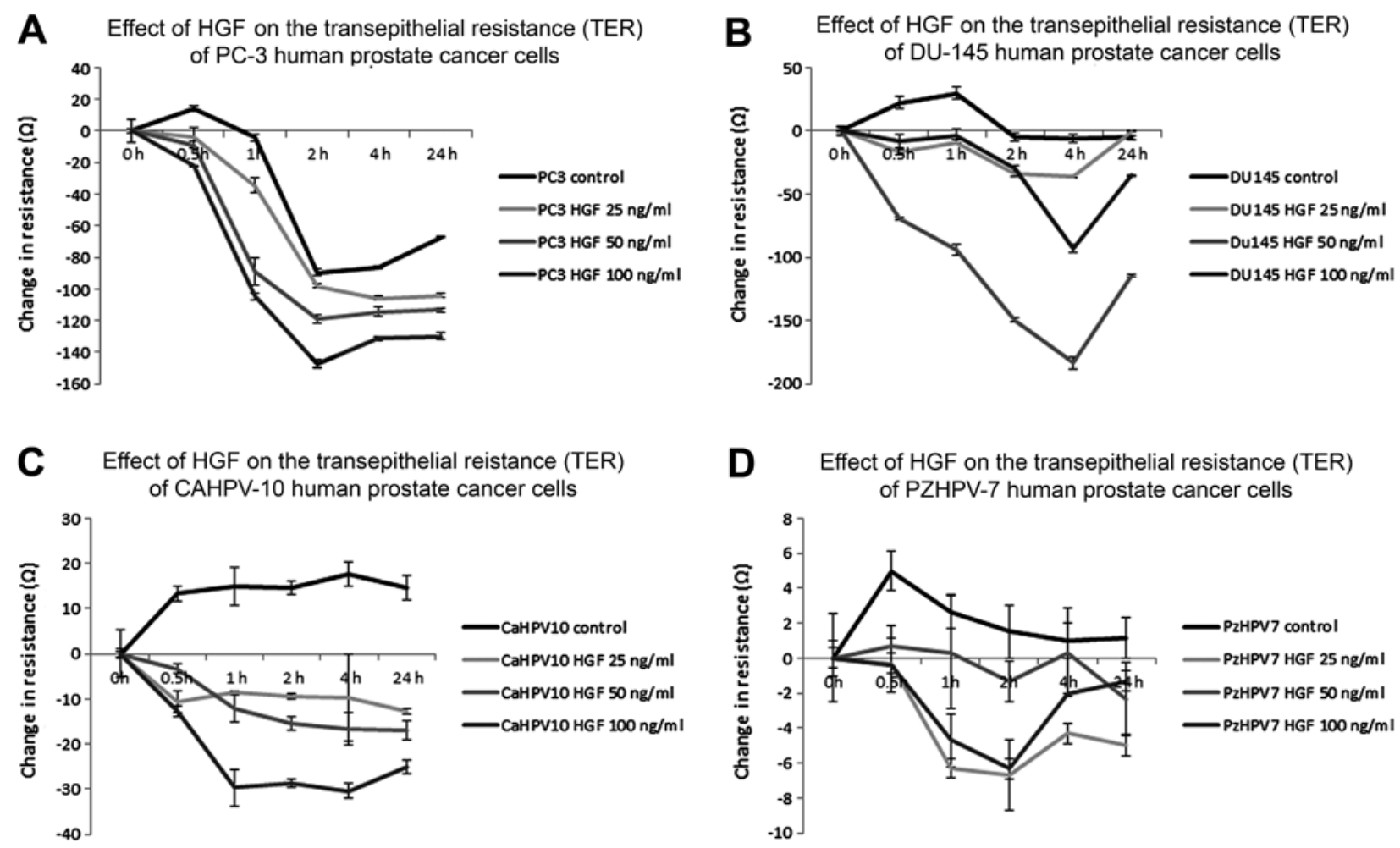

Figure 5. Effect of HGF on TJ function of human prostate cancer cells over $24 \mathrm{~h}$ of co-culture as determined by transepithelial resistance. Change in transepithelial resistance of (A) PC-3, (B) DU-145, (C) CAHPV-10 and (D) PZHPV-7 cells.

(control vs. HGF $25 \mathrm{ng} / \mathrm{ml}, \mathrm{P}=0.002 ; 50 \mathrm{ng} / \mathrm{ml}, \mathrm{P}=0.0002$; $100 \mathrm{ng} / \mathrm{ml}, \mathrm{P}=0.0005)$. CAHPV-10 cells reacted in the same way to HGF as the PC-3 cells, in that TER was reduced with increasing HGF concentration (Fig. 5C). A maximum effect was observed by a $1 \mathrm{~h}$ co-culture with HGF (control vs. HGF $25 \mathrm{ng} / \mathrm{ml}, \mathrm{P}=0.007 ; 50 \mathrm{ng} / \mathrm{ml}, \mathrm{P}=0.006 ; 100 \mathrm{ng} / \mathrm{ml}, \mathrm{P}=0.007)$. In contrast to the other three prostate cancer cell lines, PZHPV-7 cells showed maximum reduced resistance with $25 \mathrm{ng} / \mathrm{ml}$ HGF at $1 \mathrm{~h}$ (Fig. 5D); the higher concentrations of HGF also reduced TER in these cells, but not to such a great extent (control vs. HGF $25 \mathrm{ng} / \mathrm{ml}, \mathrm{P}=0.003 ; 50 \mathrm{ng} / \mathrm{ml}, \mathrm{P}=0.03 ; 100 \mathrm{ng} / \mathrm{ml}, \mathrm{P}=0.007$ ).

Changes in cell behaviour using ECIS during HGF co-culture. All four prostate cancer cell lines were treated with three concentrations of $\operatorname{HGF}(25,50$ and $100 \mathrm{ng} / \mathrm{ml})$ in order to determine the effect that HGF has on cell behaviour using ECIS. As with TER, HGF caused a concentration-dependent increase in cell attachment (Fig. 6A), with a maximum response at $20 \mathrm{~h}$ of co-culture (control vs. HGF $100 \mathrm{ng} / \mathrm{ml}$, $\mathrm{P}<0.0001)$. However, HGF at $25 \mathrm{ng} / \mathrm{ml}$ produced the greatest response in the DU-145 cells (control vs. HGF $25 \mathrm{ng} / \mathrm{ml}$, $\mathrm{P}<0.0001$ ) (Fig. 6B). This also occurred in the CAHPCV-10 cells (control vs. HGF $25 \mathrm{ng} / \mathrm{ml}, \mathrm{P}=0.0003$ ) (Fig. 6C). HGF $(100 \mathrm{ng} / \mathrm{ml})$ caused the most response in the PZHPV-7 cells (control vs. HGF $100 \mathrm{ng} / \mathrm{ml}, \mathrm{P}<0.0001$ ) (Fig. 6D).

Effect of HGF co-culture on the behaviour of normal and stem cell-like prostate cells. We then decided to investigate whether HGF had a similar effect on the TJ function of normal prostate epithelial cells. All three concentrations produced a reduced resistance in the RWPE-1 cells, as expected (Fig. 7A).
The greatest reduction was caused by $100 \mathrm{ng} / \mathrm{ml}$ HGF and no further effect was noted after $4 \mathrm{~h}$ of co-culture (at $4 \mathrm{~h}$ co-culture: control cells vs. HGF $25 \mathrm{ng} / \mathrm{ml}, \mathrm{P}=0.002$; HGF $50 \mathrm{ng} / \mathrm{ml}, \mathrm{P}=0.0008$; HGF $100 \mathrm{ng} / \mathrm{ml}, \mathrm{P}=0.0002$ ). When we carried out the same experiment on WPE-STEM prostate stem-like cells, we found that HGF caused a biphasic modulation of TJ function as assessed using TER (Fig. 7B). An initial decrease in TER at 30 min of co-culture was followed by an increase at $1 \mathrm{~h}$, then a maximum decrease again by $4 \mathrm{~h}$ of co-culture before a return to almost initial levels by $24 \mathrm{~h}$. The most marked effect was observed at an HGF concentration of $25 \mathrm{ng} / \mathrm{ml}$, followed by $50 \mathrm{ng} / \mathrm{ml}$. HGF at $100 \mathrm{ng} / \mathrm{ml}$ caused increased resistance after $1 \mathrm{~h}$ of co-culture which was higher than the control cells (at $4 \mathrm{~h}$ co-culture: control cells vs. HGF $25 \mathrm{ng} / \mathrm{ml}, \mathrm{P}=0.0002$; HGF $50 \mathrm{ng} / \mathrm{ml}, \mathrm{P}=0.003$; HGF $100 \mathrm{ng} /$ $\mathrm{ml}, \mathrm{P}=0.04)$. It is not unknown for high concentrations of HGF to elicit an inhibitory effect, and so it appears here that this may regulate the TJ function in these stem-like prostate cells.

When we used ECIS to assess the cell behaviour of RWPE-1 cells, HGF caused a concentration-dependent increase in cell attachment (control vs. HGF $100 \mathrm{ng} / \mathrm{ml}, \mathrm{P}<0.005$ ) (Fig. 7C). This was also noted in the WPE-STEM cells, although to a lesser extent (control vs. HGF $100 \mathrm{ng} / \mathrm{ml}, \mathrm{P}>0.05$ ) (Fig. 7D).

Changes in protein expression levels of TJ molecules during HGF co-culture. Three different antibodies to occludin were used, each produced to different epitopes N-terminal, $\mathrm{H}-249$ and C-terminal regions. In all the cells probed (PC-3, PZHPV-7, RWPE-1 and WPE-STEM), 4 different sizes of occludin protein were identified by the N-terminal antibody of $82 \mathrm{kDa}$, as expected: one at $70 \mathrm{kDa}$, one at $65 \mathrm{kDa}$ and one 

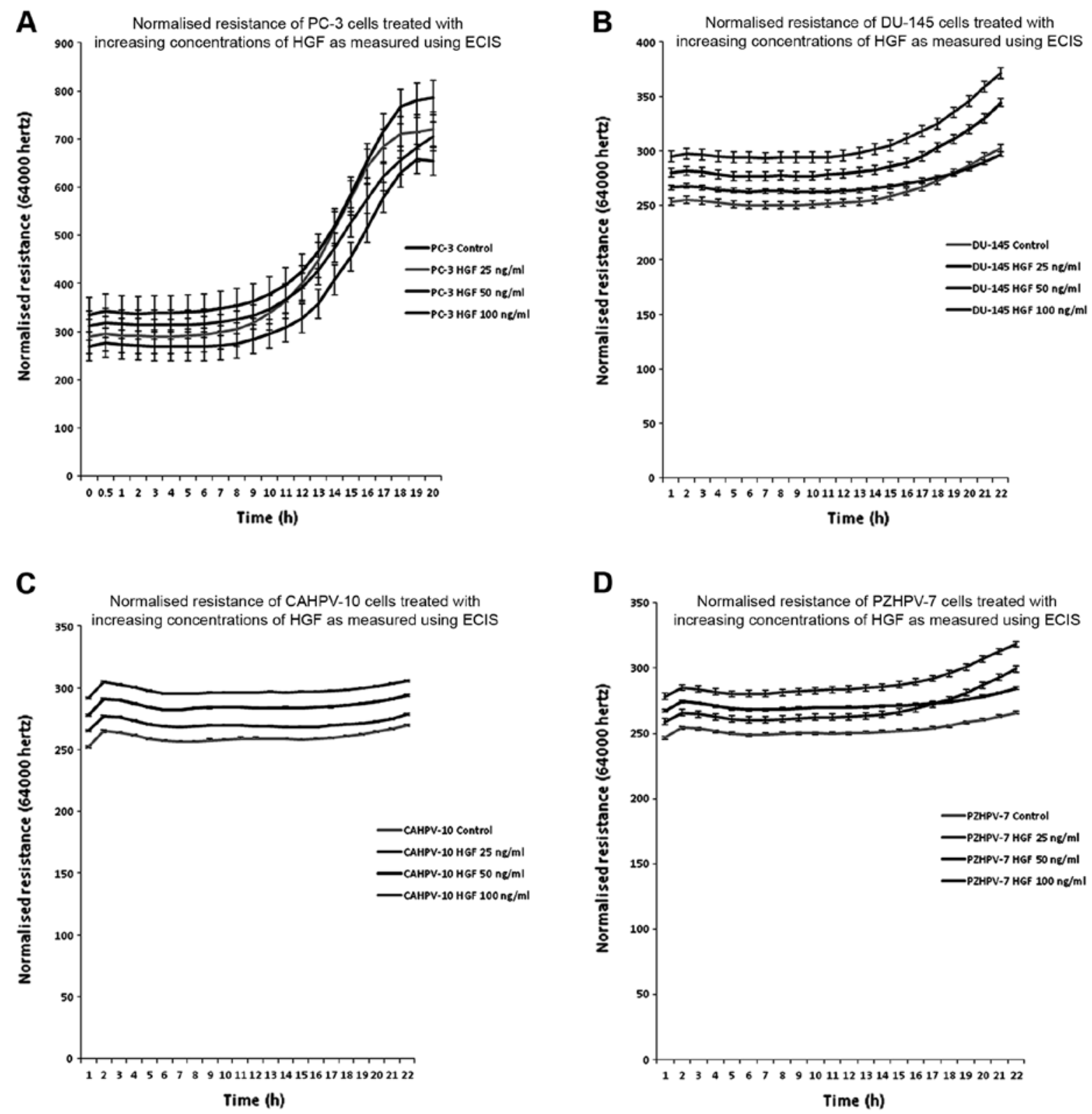

Figure 6. Effect of HGF on prostate cancer cell behaviour, assessed using ECIS. Attachment of (A) PC-3, (B) DU-145, (C) CAHPV-10 and (D) PZHPV-7 cells.

unknown protein of smaller size (Fig. 8A). The H-249 antibody identified only the $65-\mathrm{kDa}$ protein in all 4 cell lines, with an additional smaller band visible in the WPE-STEM cells. The C-terminal antibody identified two proteins in the PC-3 cells, again at 82 and $65 \mathrm{kDa}$ (shown separately with reduced exposure for clarity). Probing with the N-terminal antibody revealed an apparent time-related response to HGF with occludin reduced from $0.5 \mathrm{~h}$ of treatment for all four occludin proteins in PC-3 cells. In contrast, there was an increase in the 65-kDa protein by a $4-\mathrm{h}$ treatment with $\mathrm{HGF}$ when probing with the H-249 antibody. No change was observed with the C-terminal antibody in PC-3 cells. In the PZHPV-7 cells, there was a decrease after probing with the N-terminal antibody by $2 \mathrm{~h}$ of co-culture with HGF which returned to initial levels by $4 \mathrm{~h}$. There was no other change in occludin levels in the PZHPV-7 cells. There was some reduction in occludin levels after HGF treatment in the RWPE-1 cells (assessed by probing with the C-terminal antibody). Although there was no change noted in levels of occludin expression in the WPE-STEM cells after probing with the N-terminal antibody, a biphasic response was observed when probing with the $\mathrm{H}-249$ antibody (Fig. 8A).

Western blotting for ZO-1 in the PC-3 cells revealed two protein bands (Fig. 8B). There was an increase in protein expression for the expected 220-kDa protein by $1 \mathrm{~h}$, which continued to increase in intensity after $4 \mathrm{~h}$ of treatment with HGF, before returning to initial levels by $24 \mathrm{~h}$. The smaller protein was increased in intensity between 2 and $4 \mathrm{~h}$ of treatment with HGF, before being reduced at $24 \mathrm{~h}$. In the PZHPV-7 cells, ZO-1 was increased after $24 \mathrm{~h}$ of treatment with HGF (Fig. 8B). Levels of ZO-1 were decreased in the RWPE-1 cells after HGF treatment for $1 \mathrm{~h}$. Again, a small biphasic change in ZO-1 expression was noted in the WPE-STEM cells (Fig. 5B). Protein expression of ZO-2 was decreased after a $2 \mathrm{~h}$ treatment 
A

Effect of HGF on the transepithelial resitance (TER) of RWPE-1 human prostate epithelial cells
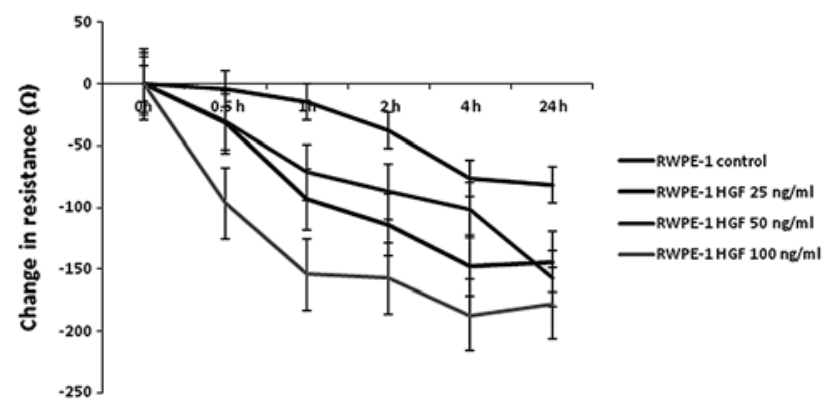

\section{C}

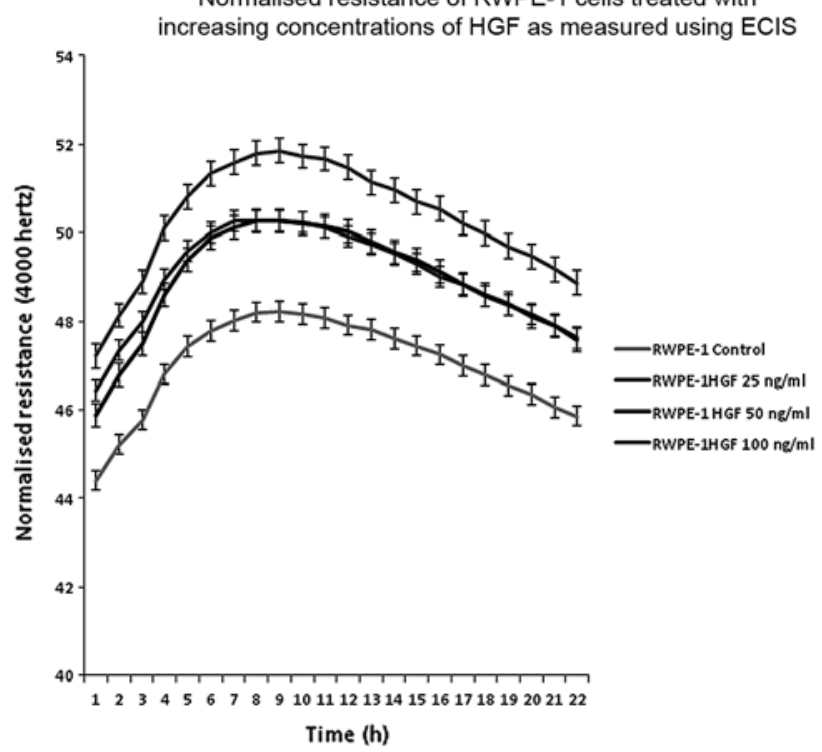

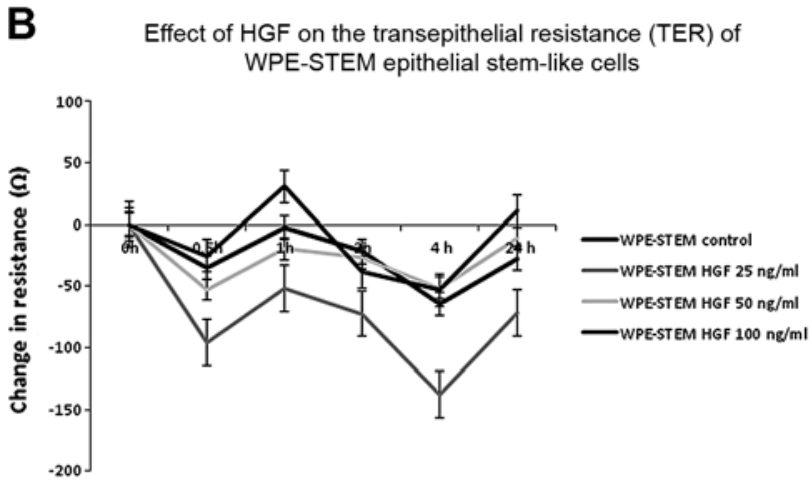

D

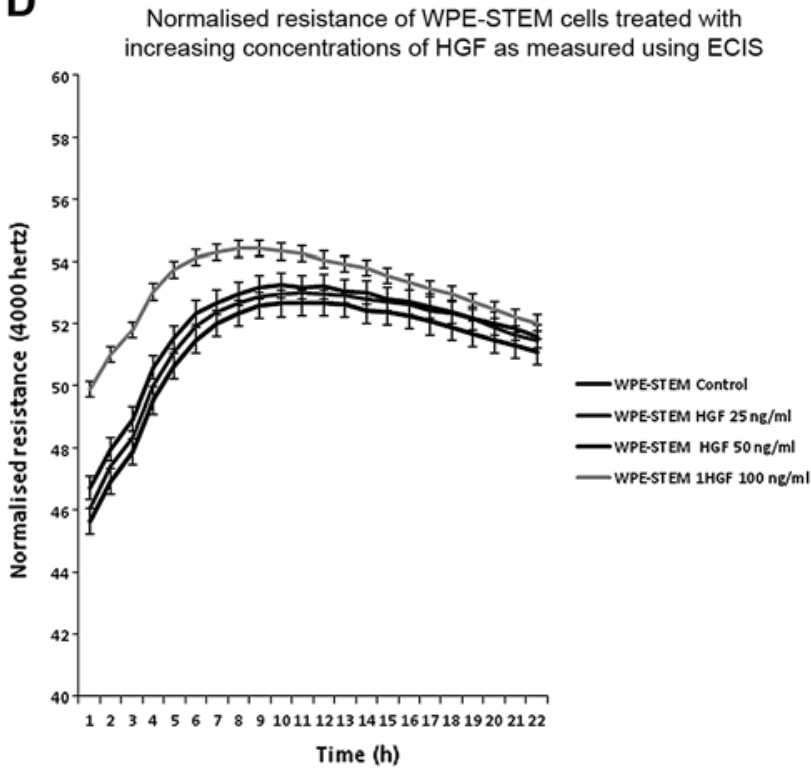

Figure 7. Effect of HGF on the behaviour of RWPE-1 and WPE-STEM cells. (A) TER of RWPE-1 cells, (B) TER of WPE-STEM cells, (C) ECIS-assessed attachment of RWPE-1 cells and (D) ECIS-assessed attachment of WPE-STEM cells.

with HGF before returning to initial levels in PC-3 cells. No change was observed in the PZHPV-7 and WPE-STEM cells. Levels of ZO-2 were increased in the RWPE-1 cells by $2 \mathrm{~h}$ of treatment with HGF (Fig. 8B). In the PC-3 cells, levels for $\mathrm{ZO}-3$, although very weak in intensity overall showed a drop at $2 \mathrm{~h}$ (Fig. 8B). This was also observed in the PZHPV-7 and WPE-STEM cells. $\beta$-actin was used as a loading control (Fig. 8C).

In vivo growth with HGF. RWPE-1 and WPE-STEM cells were used to assess tumourigenicity in an athymic nude mouse model. After 4 weeks of growth, no tumours were noted; after dissection, no evidence was observed of any growth. We can only conclude that neither cell line possessed tumourigenic properties, even in the presence of HGF.

\section{Discussion}

The present study showed that HGF, a cytokine that is strongly indicated as a regulator of tumour progression and metastasis $(25,26)$, decreased transepithelial resistance in human prostate cancer cells and cancer stem cell derivatives by modulating the expression of TJ molecules at both the transcript and protein levels and by redistribution of TJ proteins. HGF may regulate $\mathrm{TJ}$ structure formation by modulating the expression of ZO-1 and ZO-2, two TJ molecules thought to be key proteins in the regulation of TJ structure. Increasing evidence suggests that TJs may play a key role in cancer metastasis (27). We previously demonstrated that HGF promotes both migration and invasion of PC-3 prostate cancer cell (28-30).

Our previous research showed that HGF decreases transendothelial resistance, and increases paracellular permeability in both human endothelial and breast cancer cells $(2,10)$. HGF is able to cause loss of TJs, increased permeability and decreased TER in several cell types. This loss of function leads to increased chemotactic migration in retinal pigment epithelial monolayers (30). HGF regulates Sertoli-Sertoli TJs in mammalian testes, inducing a reduction in expression and a redistribution of occludin (31). HGF has also been shown to promote the relocalisation of ZO-1 from TJs to the cytoplasm in MDCK cells (32) and to decrease TER in a non-tumoural gastric epithelial cell line (33); a similar result in T84 human intestinal cells (34), but not in tracheal epithelial cells (35).

Conversely, a number of studies have shown that in certain cases, HGF provides a protective effect against TJ disruption. This was demonstrated in cerebrovascular endothelial 
A $\mathrm{PC}-3$

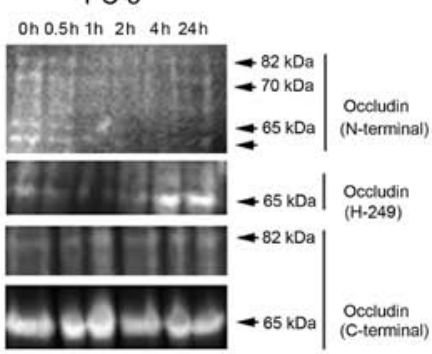

PZHPV-7

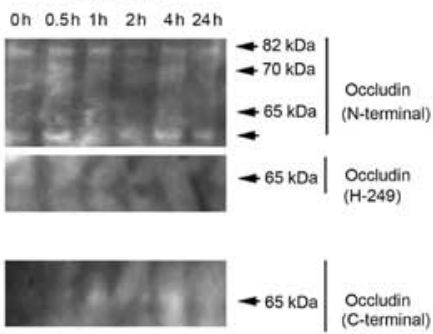

PZHPV-7

On $0.5 \mathrm{~h}$ 1h $2 \mathrm{~h} 4 \mathrm{~h} 24 \mathrm{~h}$

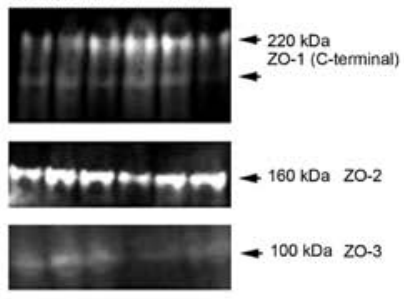

C

PC-3

Oh $0.5 \mathrm{~h}$ ih $2 \mathrm{~h}$ 4h $24 \mathrm{~h}$

$\longrightarrow+45 \mathrm{kDa} \quad \beta$-actin on $0.5 \mathrm{~h}$ in $2 \mathrm{~h} 4 \mathrm{~h} 24 \mathrm{~h}$

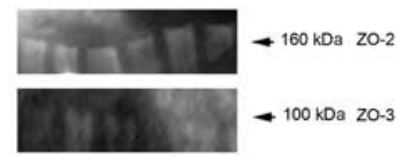

PZHPV-7

Oh $0.5 \mathrm{~h}$ ih $2 \mathrm{~h} 4 \mathrm{~h} 24 \mathrm{~h}$

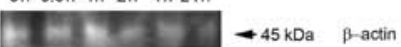

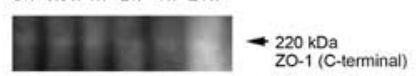

RWPE-1

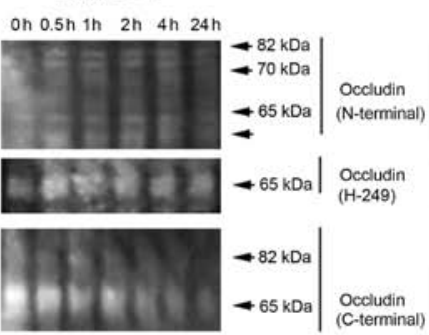

RWPE-1

Oh $0.5 \mathrm{~h}$ th $2 \mathrm{~h} 4 \mathrm{~h} 24 \mathrm{~h}$
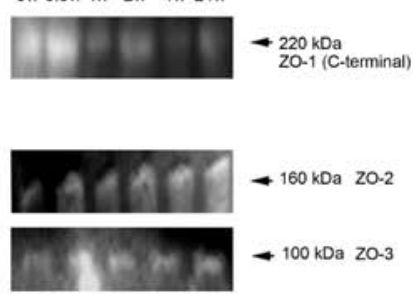

RWPE-1

on $0.5 \mathrm{~h}$ in $2 \mathrm{~h} 4 \mathrm{~h} 24 \mathrm{~h}$

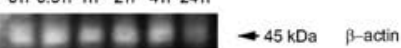

WPE-STEM

oh $0.5 \mathrm{~h}$ ih $2 \mathrm{~h} 4 \mathrm{~h} 24 \mathrm{~h}$

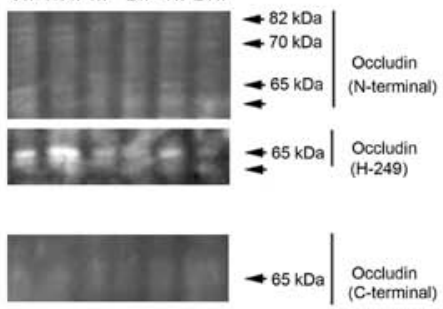

WPE-STEM

oh $0.5 \mathrm{~h}$ ih $2 \mathrm{~h} 4 \mathrm{~h} 24 \mathrm{~h}$
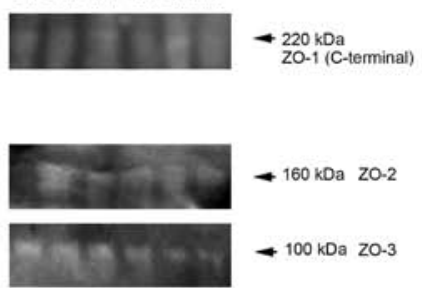

WPE-STEM

on $0.5 \mathrm{~h}$ in $2 \mathrm{~h} \quad 4 \mathrm{~h} 24 \mathrm{~h}$

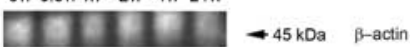

Figure 8. Effect of HGF $(25 \mathrm{ng} / \mathrm{ml})$ on the protein expression of TJ proteins over $24 \mathrm{~h}$ of co-culture in human prostate cells. (A) Change in expression of occludin, probed with antibodies mapping to 3 different epitopes. (B) Change in expression in ZO-1, ZO-2 and ZO-3. (C) $\beta$-actin levels shown for loading control.

cells, where treatment with recombinant HGF attenuated the decrease in expression of occludin and ZO-1 after sustained cerebral ischemia (36). In addition, HGF increases TER in uterine epithelial cells (37). In human pulmonary artery endothelial cells, HGF rapidly and dose-dependently increased transendothelial resistance (38), although there was no examination of the expression of any TJ molecules. This present work is the first study to examine the effect of HGF on TJs in prostate cancer cells. PC-3 cells had reduced transepithelial resistance and increased paracellular permeability resulting in reduced barrier function upon addition of HGF.

RT-PCR revealed that HGF modulated the expression of a number of TJ molecules, a response that was consistent over numerous experiments $(\mathrm{n}=5)$. The loss of expression of $\mathrm{ZO}-1$, ZO-2 and ZO-3 was an expected response to HGF. However, the increase in expression of occludin was not foreseen, as was the lack of response to HGF by claudin-1 and claudin- 5 . At the protein level, there was an apparent initial increase in expression of ZO-1, followed by a reduction. There was also a signal for two proteins after probing with $\mathrm{ZO}-1$, a phenomenon we had not previously observed. There was some loss of ZO-2 and ZO-3 at the protein level, but this did not follow the observations of changes in expression at the RNA level. The increased message level of occludin was not reflected by the protein levels of occludin, as probed using an antibody with an epitope to the $\mathrm{N}$-terminal region of the protein. However, after probing with a second antibody with an epitope mapping to a more central region of occludin, there was a concurrent increase in occludin signal of the $65-\mathrm{kDa}$ size.
A possible explanation for the inconsistency of reduced expression in message to protein following HGF stimulation may be that the possible reduction in protein was reflected, but that protein degradation occurs much more slowly than that of mRNA. Consequently, as the mRNA levels of ZO-1 and ZO-2 began to decrease after $1 \mathrm{~h}$ of incubation with HGF, we did not see an equivalent reduction in protein. Occludin at the high molecular weight level was reduced after a 0.5 -h incubation with HGF. An extra band was also observed at $\sim 70 \mathrm{kDa}$. We previously demonstrated this band in human breast cancer cells (10). Previous reports have shown that phosphorylation of serine residues on occludin increases the formation of TJs (25) and that occludin confers adhesiveness in proportion to the level of protein expressed (39). Phosphorylation of occludin is probably an important step in regulating TJ formation and permeability. Farshori and Kachar (40) have shown that, in MDCK epithelial cell monolayers, the 62-65 kDa occludin bands are phosphorylated on serine and threonine, whereas the $71-\mathrm{kDa}$ band is phosphorylated on serine only. Wong (41) described the appearance of two clusters of occludin in MDCK cells: one group of low molecular weight (LMW) of $\sim 65-68 \mathrm{kDa}$, and one group of high molecular weight (HMW) of 70-75 kDa. LMW occludins are found in cells that have no cell-cell contact, i.e. no intact TJs. The HMW occludins (hyperphosphorylated LMWs) are the functional forms of occludin that participate in the formation of the TJ barrier. Such results suggest that the phosphorylation of occludin may be a mechanism by which localisation and function are regulated. We have seen that a decrease in HMW occludin in breast 
cancer cell lines, upon addition of HGF, corresponds to loss of TJ integrity, and so to a loss of TJ function (10).

Based on our data here, there was an increase in levels of the $65-\mathrm{kDa}$ occludin band suggesting, that in these cells, HGF caused an increase in serine and threonine phosphorylation, with a concurrent reduction in serine-only phosphorylated occludin. This could thus lead to a reduction in TJ integrity, as serine-only phosphorylated occludin is required for $\mathrm{TJ}$ formation in cell types that express occludin. The apparent disparity in expression pattern between occludin antibodies of various epitopes might reflect the sensitivities of these antibodies to changes in phosphorylation status.

It has been shown that phosphorylation of the tyrosine residues on ZO-1 may result in the dismantling of TJs and a decrease in TER (25), which we also showed to contribute to changes in TJ formation in human breast cancer cells (10). $\mathrm{ZO}$ proteins are involved in the organisation of epithelial and endothelial intercellular junctions, binding to the cytoplasmic carboxyl termini of junctional transmembrane proteins and so linking them to the actin cytoskeleton. HGF-induced ZO-1 phosphorylation may contribute to the disassembly of the TJ complex, resulting in transient disruption of TJ function. The two ZO-1 proteins observed expressed by PC-3 cells may reflect a difference in phosphorylation status of $\mathrm{ZO}-1$ in these cells.

Early research on claudins suggested that tissue expression patterns varied between different claudin species (42). It is evident from our study here, that HGF has no effect on the expression of either claudin- 1 or claudin- 5 in these human prostate cells. Immunostaining with ZO-1, ZO-2, ZO-3, occludin, claudin- 1 and claudin- 5 showed that HGF affected the distribution of these TJ molecules. After co-culture with HGF, there was a more densely stained cytoplasm and relocation of ZO-1 to ruffled membrane areas of the cells. Both ZO-2 and ZO-3 showed a loss of signal at the TJ region with increased cytoplasmic staining in the case of $\mathrm{ZO}-2$. $\mathrm{ZO}-3$ expression remained less strong throughout the experiment overall. Occludin staining was well defined and following treatment with HGF became dotty and discontinuous with increased cytoplasmic staining. There was also a concurrent loss in TJ location of both claudins.

As stated in the introduction, there have been few studies investigating the role of TJs in prostate cancer cells and those that have been carried out were focused on the claudin family of proteins. Studies using clinical samples have shown that claudin-1 is lost in prostate adenocarcinoma (16) as discovered using immunohistochemistry. In LNcaP prostate cells, two isoforms of claudin-7 were found to regulate the expression of PSA, with the truncated form predominantly expressed in healthy prostate tissues (18). In addition, occludin was observed to be lost in unpolarized cells of Gleason grades 4 and $5(n=64)$ with general downregulation associated with loss of cell polarity (43). There have been no reports of the modulation of TJ function and formation in human prostate cancer cells.

Claudin proteins have been targeted as a means of modulating $\mathrm{TJ}$ function. Tight junctions in human prostate cells can be modulated successfully, as shown by a study suggesting that flavonoids extracted from Orostachys japonicus A. Berger suppressed cancer migration and invasion by tightening
TJs through the suppression of claudin expression, and by suppressing MMPs in LNCaP human prostate cancer cells, which at least in part resulted from the suppression of the PI3K/Akt signaling pathway (44).

Moreover, in mice, low serum testosterone has been associated with reduced transcript and protein levels of claudin-4 and claudin-8, resulting in defective TJ ultrastructure in benign prostate glands. Expression of claudin- 4 and claudin- 8 was negatively correlated with the mononuclear inflammatory infiltrate caused by testosterone deprivation. Testosterone suppression also induced an autoimmune humoral response directed toward prostatic proteins. Testosterone supplementation in castrated mice resulted in re-expression of TJ components in prostate epithelium and significantly reduced prostate inflammatory cell numbers. These data demonstrate that TJ architecture in the prostate is related to changes in serum testosterone levels, and identify an androgen-regulated mechanism that potentially contributes to the development of prostate inflammation and consequent pathology (45). In targeting TJs, CPE-mediated cytotoxicity was observed in human prostate cancer cell lines, but was barely detected in normal human PrECs. The cytotoxic effect depended not only on the expression level of Claudin-4 protein but also on its subcellular localization. These results suggest that Claudin-4-targeted therapy using CPE may be a new treatment for prostate cancer (46).

The WPE-STEM cells demonstrated a difference in response to treatment with $\mathrm{HGF}$, which may have a direct bearing on their stem cell-like phenotype. It has been shown that HGF secreted by prostate cancer stem-like cells/cancer-initiating cells and prostate myofibroblasts has a role in the maintenance of prostate cancer stem-like cells/cancer-initiating cells in an autocrine and paracrine manner (47). In mice, immunohistochemical analysis in prostatectomies revealed significant enrichment of c-MET-positive cells at the invasive front, and demonstrated co-expression of c-MET with stem-like markers CD49b and CD49f. In conclusion, activation of c-MET in prostate cancer cells induced a stem-like phenotype, indicating a dynamic relation between differentiated and stem-like cells in this malignancy. Its mediation of efficient tumour formation in vivo and predominant receptor expression at the invasive front indicate that c-MET regulates tumour infiltration in surrounding tissues putatively by acquisition of a stem-like phenotype (48).

The rapidly increasing studies linking TJ function and regulation with cancer cell dissociation, motility and invasion, all events involved in metastasis, strongly suggest that TJs are a key element in the prevention of cancer cell dissemination.

In conclusion, from the data presented here, we can conclude that HGF, a cytokine known to be involved in metastatic progression, disrupts the TJs of human prostate cancer cells. HGF affects this disruption by: i) modulating TJ molecule transcripts and ii) modulating the protein expression of $\mathrm{ZO}-1, \mathrm{ZO}-2$ and occludin. These changes were concurrent with relocation of ZO-1, ZO-2, ZO-3, occludin and claudin-1 and claudin-5 from the TJ locality. Both occludin and ZO-1 showed some relocation to the ruffled membrane areas of migrating cells. The disruption of the TJ structure by HGF could thus be an initial event in the metastasis of human prostate cancer cells and as such requires further investigation to evaluate its usefulness as a target for anti-metastasis intervention. 


\section{Acknowledgements}

The authors would like to thank Cancer Research Wales for supporting their work and Dr Jane Lane for proof-reading the manuscript.

\section{References}

1. Martin TA, Watkins G, Mansel RE and Jiang WG: Loss of tight junction plaque molecules in breast cancer tissues is associated with a poor prognosis in patients with breast cancer Eur J Cancer 40: 2717-2725, 2004.

2. Martin TA, Mansel RE and Jiang WG: Antagonistic effect of NK4 on $\mathrm{HGF} / \mathrm{SF}$ induced changes in the transendothelial resistance (TER) and paracellular permeability of human vascular endothelial cells. J Cell Physiol 192: 268-275, 2002.

3. Ren J, Hamada J, Takeichi N, Fujikawa S and Kobayashi H: Ultrastructural differences in junctional intercellular communication between highly and weakly metastatic clones derived from rat mammary carcinoma. Cancer Res 50: 358-362, 1990.

4. Satoh $\mathrm{H}$, Zhong $\mathrm{Y}$, Isomura $\mathrm{H}$, et al: Localization of 7H6 tight junction-associated antigen along the cell border of vascular endothelial cells correlates with paracellular barrier function against ions, large molecules, and cancer cells. Exp Cell Res 222: 269-274, 1996.

5. Hoevel T, Macek R, Mundigl O, Swisshelm K and Kubbies M: Expression and targeting of the tight junction protein CLDN1 in CLDN1-negative human breast tumor cells. J Cell Physiol 191: 60-68, 2002.

6. Kominsky SL, Argani P, Korz D, et al: Loss of the tight junction protein claudin-7 correlates with histological grade in both ductal carcinoma in situ and invasive ductal carcinoma of the breast. Oncogene 22: 2021-2033, 2003.

7. Krämer F, White K, Kubbies M, Swisshelm K and Weber BH: Genomic organization of claudin-1 and its assessment in hereditary and sporadic breast cancer. Hum Genet 7: 249-256, 2002.

8. Chlenski A, Ketels KV, Korovaitseva GI, Talamonti MS, Oyasu R and Scarpelli DG: Organization and expression of the human zo-2 gene (tjp-2) in normal and neoplastic tissues. Biochim Biophys Acta 1493: 319-324, 2000.

9. Bell J, Walsh S, Nusrat A and Cohen C: Zonula occludens-1 and Her-2/neu expression in invasive breast carcinoma. Appl Immunohistochem Mol Morphol 11: 125-129, 2003.

10. Martin TA, Watkins G, Mansel RE and Jiang WG: Hepatocyte growth factor disrupts tight junctions in human breast cancer cells. Cell Biol Int 28: 361-371, 2004.

11. Ikenouchi J, Matsuda M, Furuse M and Tsukita S: Regulation of tight junctions during the epithelium-mesenchyme transition: direct repression of the gene expression of claudins/occludin by Snail. J Cell Sci 116: 1959-1967, 2003.

12. Martin TA, Goyal A, Watkins G and Jiang WG: Expression of the transcription factors snail, slug, and twist and their clinical significance in human breast cancer. Ann Surg Oncol 12: 488-496, 2005.

13. Ohkubo T and Ozawa M: The transcription factor Snail downregulates the tight junction components independently of E-cadherin downregulation. J Cell Sci 117: 1675-1685, 2004.

14. Gopalakrishnan S, Raman N, Atkinson SJ and Marrs JA: Rho GTPase signaling regulates tight junction assembly and protects tight junctions during ATP depletion. Am J Physiol 275: C798-C809, 1998.

15. Wong V and Gumbiner BM: A synthetic peptide corresponding to the extracellular domain of occludin perturbs the tight junction permeability barrier. J Cell Biol 136: 399-409, 1997.

16. Krajewska M, Olson AH, Mercola D, Reed JC and Krajewski S: Claudin-1 immunohistochemistry for distinguishing malignant from benign epithelial lesions of prostate. Prostate 67: 907-910, 2007.

17. Hewitt KJ, Agarwal R and Morin PJ: The claudin gene family: expression in normal and neoplastic tissues. BMC Cancer 6: 186, 2006.

18. Zheng JY, Yu D, Foroohar M, Ko E, Chan J, Kim N, Chiu R and Pang S: Regulation of the expression of the prostate-specific antigen by claudin-7. J Membr Biol 194: 187-197, 2003.

19. Long H, Crean CD, Lee WH, Cummings OW and Gabig TG: Expression of Clostridium perfringens enterotoxin receptors claudin-3 and claudin-4 in prostate cancer epithelium. Cancer Res 61: 7878-7881, 2001.
20. Meyer HW, Freytag C, Freytag T and Richter W: Effect of proteases and other treatments on the proliferative assembly of tight junction strands in the rat prostate tissue. Exp Pathol 34: 237-244, 1998

21. Kachar B and Reese TS: Evidence for the lipidic nature of tight junction strands. Nature 296: 464-466, 1982.

22. Kachar B and Reese TS: Formation of misplaced and reflexive tight junction strands in prostate epithelial cells. J Ultrastruct Res 82: 90-95, 1983

23. Kachar B and Pinto da Silva P: Rapid massive assembly of tight junction strands. Science 213: 541-544, 1981.

24. Martin TA, Das T, Mansel RE and Jiang WG: Enhanced tight junction function in human breast cancer cells by antioxidant, selenium and polyunsaturated lipid. J Cell Biochem 101: 155-166, 2007.

25. Jiang WG, Martin TA, Matsumoto K, Nakamura $\mathrm{T}$ and Mansel RE: Hepatocyte growth factor/scatter factor decreases the expression of occludin and transendothelial resistance (TER) and increases paracellular permeability in human vascular endothelial cells. J Cell Physiol 181: 319-329, 1999.

26. Rosen EM, Zitnik RJ, Elias JA, Bhargava MM, Wines J and Goldberg ID: The interaction of HGF-SF with other cytokines in tumor invasion and angiogenesis. EXS 65: 301-310, 1993.

27. Martin TA and Jiang WG: Tight junctions and their role in cancer metastasis. Histol Histopathol 16: 1183-1195, 2001

28. Hurle RA, Davies G, Parr C, Mason MD, Jenkins SA, Kynaston HG and Jiang WG: Hepatocyte growth factor/scatter factor and prostate cancer: a review. Histol Histopathol 20: 1339-1349, 2005.

29. Davies G, Jiang WG and Mason MD: Matrilysin mediates extracellular cleavage of E-cadherin from prostate cancer cells: a key mechanism in hepatocyte growth factor/scatter factor-induced cell-cell dissociation and in vitro invasion. Clin Cancer Res 7: 3289-3297, 2001

30. Jin M, Barron E, He S, Ryan SJ and Hinton DR: Regulation of RPE intercellular junction integrity and function by hepatocyte growth factor. Invest Ophthalmol Vis Sci 43: 2782-2790, 2002.

31. Catizone A, Ricci G and Galdieri M: Hepatocyte growth factor modulates Sertoli-Sertoli tight junction dynamics. J Cell Physiol 216: 253-260, 2008.

32. Grisendi S, Arpin M and Crepaldi T: Effect of hepatocyte growth factor on assembly of zonula occludens-1 protein at the plasma membrane. J Cell Physiol 176: 465-471, 1998.

33. Hollande F, Blanc EM, Bali JP, Whitehead RH, Pelegrin A, Baldwin GS and Choquet A: HGF regulates tight junctions in new nontumorigenic gastric epithelial cell line. Am J Physiol Gastrointest Liver Physiol 280: G910-G921, 2001.

34. Nusrat A, Parkos CA, Bacarra AE, Godowski PJ, Delp-Archer C, Rosen EM and Madara JL: Hepatocyte growth factor/scatter factor effects on epithelia. Regulation of intercellular junctions in transformed and nontransformed cell lines, basolateral polarization of c-met receptor in transformed and natural intestinal epithelia, and induction of rapid wound repair in a transformed model epithelium. J Clin Invest 93: 2056-2065, 1994.

35. Shen BQ, Panos RJ, Hansen-Guzmán K, Widdicombe JH and Mrsny RJ: Hepatocyte growth factor stimulates the differentiation of human tracheal epithelia in vitro. Am J Physiol 272: L1115-L1120, 1997.

36. Date I, Takagi N, Takagi K, Tanonaka K, Funakoshi H, Matsumoto K, Nakamura T and Takeo S: Hepatocyte growth factor attenuates cerebral ischemia-induced increase in permeability of the blood-brain barrier and decreases in expression of tight junctional proteins in cerebral vessels. Neurosci Lett 407: 141-145, 2006.

37. Grant-Tschudy KS and Wira CR: Hepatocyte growth factor regulation of uterine epithelial cell transepithelial resistance and tumor necrosis factor alpha release in culture. Biol Reprod 72: 814-821, 2005.

38. Liu F, Schaphorst KL, Verin AD, Jacobs K, Birukova A, Day RM, Bogatcheva N, Bottaro DP and Garcia JG: Hepatocyte growth factor enhances endothelial cell barrier function and cortical cytoskeletal rearrangement: potential role of glycogen synthase kinase-3beta. FASEB J 16: 950-962, 2002.

39. Fanning AS, Mitic LL and Anderson JM: Transmembrane proteins in the tight junction barrier. J Am Soc Nephrol 10: 1337-1345, 1999.

40. Farshori $P$ and Kachar B: Redistribution and phosphorylation of occludin during opening and resealing of tight junctions in cultured epithelial cells. J Membr Biol 170: 147-156, 1999.

41. Wong V: Phosphorylation of occludin correlates with occludin localization and function at the tight junction. Am J Physiol 273: C1859-C1867, 1997. 
42. Morita K, Furuse M, Fujimoto K and Tsukita S: Claudin multigene family encoding four-transmembrane domain protein components of tight junction strands. Proc Natl Acad Sci USA 96: 511-516, 1999.

43. Busch C, Hanssen TA, Wagener C and OBrink B: Down-regulation of CEACAM1 in human prostate cancer: correlation with loss of cell polarity, increased proliferation rate, and Gleason grade 3 to 4 transition. Hum Pathol 33: 290-298, 2002.

44. Shin DY, Lee WS, Jung JH, et al: Flavonoids from Orostachys japonicus A. Berger inhibit the invasion of $\mathrm{LNCaP}$ prostate carcinoma cells by inactivating Akt and modulating tight junctions. Int J Mol Sci 14: 18407-18420, 2013.

45. Meng J, Mostaghel EA, Vakar-Lopez F, Montgomery B, True L and Nelson PS: Testosterone regulates tight junction proteins and influences prostatic autoimmune responses. Horm Cancer 2 : 145-156, 2011.
46. Maeda T, Murata M, Chiba H, Takasawa A, Tanaka S, Kojima T, Masumori N, Tsukamoto T and Sawada N: Claudin-4-targeted therapy using Clostridium perfringens enterotoxin for prostate cancer. Prostate 72: 351-360, 2012.

47. Nishida S, Hirohashi Y, Torigoe T, Inoue R, Kitamura H, Tanaka T, Takahashi A, Asanuma H, Masumori N, Tsukamoto T and Sato N: Prostate cancer stem-like cells/cancer-initiating cells have an autocrine system of hepatocyte growth factor. Cancer Sci 104: 431-436, 2013.

48. van Leenders GJ, Sookhlall R, Teubel WJ, de Ridder CM, Reneman S, Sacchetti A, Vissers KJ, van Weerden W and Jenster G: Activation of c-MET induces a stem-like phenotype in human prostate cancer. PLoS One 6: e26753, 2001. 